\title{
Acquired anterior staphyloma after corneal ulcer associated with the use of crack
}

\author{
Estafiloma anterior adquirido após úlcera de córnea associado a uso de crack
}

\author{
Stefânia Barbosa Diniz de Vasconcelos ${ }^{1}$, Fernanda Machado Guerra ${ }^{1}$, Gisele Macioca Morato ${ }^{1}$, Nathália Teles das Neves ${ }^{1}$, Patrick Frensel Tzelikis ${ }^{1}$
}

\begin{abstract}
We describe an unusual case of acquired anterior staphyloma in a patient addicted to crack cocaine. At the beginning of his crack cocaine abuse, he noticed redness and irritation of his eyes. Over the next 4 months, the patient also noticed the onset of decreasing visual acuity in his right eye (OD). Initially, his visual acuity was light perception in OD, and slit-lamp examination revealed a corneal infiltrate with a peripheral perforation and an iris prolapse. The patient was hospitalized to ensure compliance with the prescribed treatment and was advised to undergo therapeutic keratoplasty; however, the patient left the hospital against medical advice and was lost to follow-up for the next 6 months. He returned with complaints of photophobia and the inability to close his right eyelids. At this time, his cornea had developed an anterior staphyloma and required a sclerokeratoplasty. Following surgery, the patient was again lost to follow-up.
\end{abstract}

Keywords: Eye infection/etiology; Corneal ulcer/complications; Crack cocaine/ adverse effects

\begin{abstract}
RESUMO
Descrevemos um raro caso de estafiloma anterior adquirido em um paciente viciado em crack. No início do uso do crack, paciente observou hiperemia e irritação nos seus olhos. Durante os próximos 4 meses, evoluiu com piora progressiva da visão em seu olho direito $(O D)$. Inicialmente, sua visão no OD era de percepção luminosa e ao exame de biomicroscopia observava-se um importante infiltrado corneano com uma perfuração periférica e hérnia de íris. O paciente foi hospitalizado para garantir seu correto tratamento e indicado ceratoplastia terapêutica; no entanto, o paciente abandou o hospital e ficou 6 meses sem acompanhamento. Após esse período, paciente retornou queixando-se de importante fotofobia e inabilidade em ocluir O OD. Neste momento, sua córnea havia desenvolvido um importante estafiloma anterior e necessitou de uma escleroceratoplastia no OD. Após a cirurgia, mais uma vez o paciente abandonou o tratamento e perdeu o seguimento pós-operatório.
\end{abstract}

Descritores:Infecção ocular/etiologia; Úlcera de córnea/complicações; Cocainacrack/ efeitos adversos

\section{INTRODUCTION}

Staphyloma is an abnormal protrusion of the uveal tissue through a weak point of the eye. Acquired anterior staphyloma occurs subsequent to corneal perforation, usually following untreated or non-responding infective keratitis ${ }^{(1)}$. Anterior staphylomas are rarely observed in patients with Peters anomaly ${ }^{(2)}$.

Various ocular complications that are associated with crack cocaine have been reported, including epitheliopathy, microbial keratitis, and corneal perforation ${ }^{(3-5)}$. Such manifestations result from many factors, ranging from direct drug effects to the social environment of the patient.

Treatment options in cases of anterior staphyloma include penetrating keratoplasty, mushroom grafts, sclerokeratoplasty, and dural patch $^{(6-8)}$.

We report a case of acquired anterior staphyloma following perforation of a corneal ulcer in a patient who used crack cocaine daily for 6 months prior to the second presentation and its management.

\section{CASE REPORT}

A 30-year-old black man presented with a 4-week history of a foreign body sensation, redness, and pain in his right eye. His left eye was stable. The patient had a history of crack cocaine and injected heroin abuse. He was homeless and admitted to using crack cocaine daily over the past 4 months. He denied any previous contact lens use, trauma, or ocular surgery. He was otherwise quite well with no systemic symptoms, and his general medical history was unremarkable.

On examination at our hospital, uncorrected visual acuity was found to be light perception (LP) in the right eye and 20/25 in the left eye. Slit-lamp examination of the right eye revealed an inflamed conjunctiva, a total epithelial defect, a large $5.0 \times 6.0$-mm full-thickness stromal infiltrate, and a peripheral corneal perforation with an incarceration of the iris and a flat anterior chamber. Left eye examination revealed inferior superficial punctate keratopathy without the evidence of an infection. The patient was offered imminent penetrating keratoplasty in his right eye; however, he was lost to follow-up for the next 6 months. He then returned to hospital with complaints of light sensitivity and difficulty in closing his right eye. On examination, his visual acuity was still LP, and he was found to have protrusion and extreme thinning of the entire cornea. The appearance of the protruded area was similar to a blueberry in color, size, and shape (Figure 1). The iris appeared to adhere to the entire cornea. Lens status could not be ascertained because the lens was not visible. The patient was diagnosed with an acquired anterior staphyloma resulting from corneal perforation, with plugging of the defect by the iris, and possibly related to an initial corneal epithelial defect that was associated with crack cocaine abuse. At this time, the patient agreed to surgical intervention.

The patient underwent a sclerokeratoplasty in his right eye prepared freehand. The recipient eye underwent a $360^{\circ}$ peritomy; next a $360^{\circ}$ sclerokeratectomy was performed. It was noted that the entire lesion was filled with an aqueous humor, and the iris was adherent to a fibrous membrane that had replaced the cornea. The crystalline lens was found to be in place. The donor graft was prepared freehand and sutured to the recipient scleral bed with 10-0 nylon; the knots were rotated into the patient's sclera (Figure 2). The conjunctiva was closed, and subconjunctival antibiotics and steroids were injected.
Submitted for publication: July 30, 2015

Accepted for publication: October 29, 2015

Hospital de Base do Distrito Federal, Brasilia, DF, Brazil.
Funding: No specific financial support was available for this study.

Disclosure of potential conflicts of interest: None of the authors have any potential conflicts of interest to disclose.

Corresponding author: Patrick Frensel Tzelikis. SQN 203, BI. K, ap. 502 - Brasília, DF - 70833-110 Brazil -E-mail: tzelikis@gmail.com 


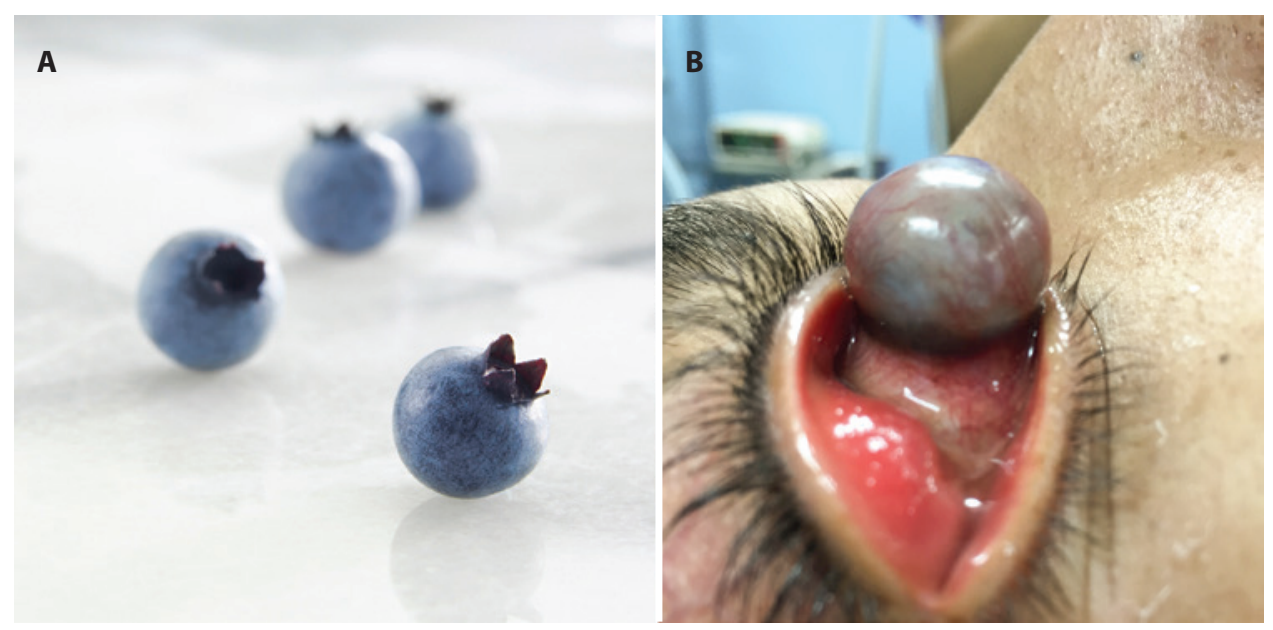

Figure 1. A) Typical appearance of blueberries. B) Acquired anterior staphyloma following a corneal ulcer with a severe bulging of the right eye at the time of the surgery.

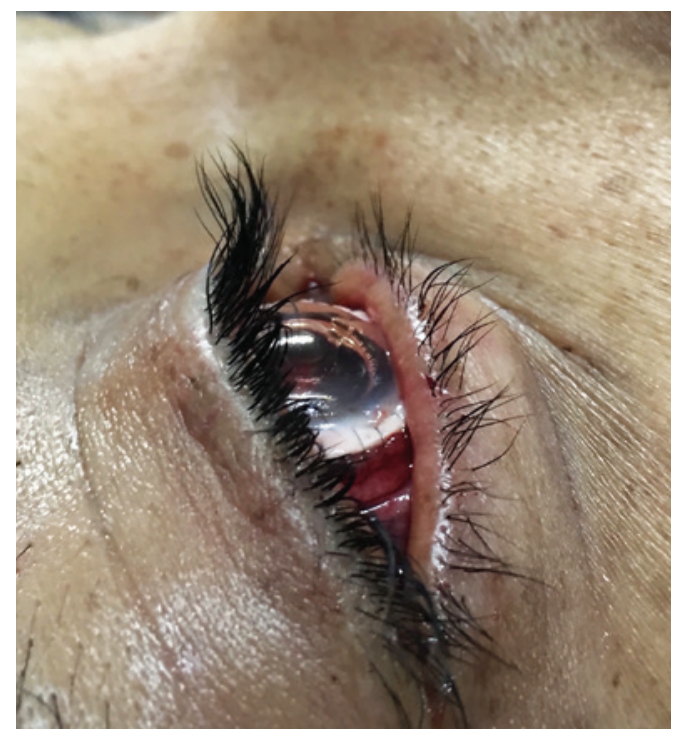

Figure 2. The immediate postoperative appearance of the eye.

On the first postoperative day, ocular hypertension developed and medical treatment was initiated. His visual acuity was hand motions. Unfortunately, the patient was again lost to follow-up and never returned following the procedure.

\section{DISCUSSION}

Here we describe a case of anterior staphyloma. A few cases of acquired anterior staphyloma associated with drug abuse have been reported in the literature. In 1989, McHenry et al. ${ }^{(9)}$ first described corneal epithelial defects that were associated with crack cocaine. Since then, others have reported regarding corneal damage caused by narco$\operatorname{tics}^{(3-5)}$. This is the first case that is associated with anterior staphyloma.

Acquired anterior staphylomas most frequently occurs because of untreated perforated ulcers ${ }^{(1)}$. When the cornea perforates, the iris plugs the wound, and a pseudocornea forms over the iris. It is unable to withstand the intraocular pressure, and thus, progressively protrudes. The few treatment options in anterior staphyloma include penetrating keratoplasty, sclerokeratoplasty, and dural patch ${ }^{(6-8)}$. Besides increased complexity of large graft surgery resulting from loss of limbal support and subsequent protrusion of the lens-iris diaphragm during surgery, the poorer outcomes observed in these types of procedures are multifactorial, including extensive initial infection, postoperative chronic ocular surface and anterior segment inflammation, and secondary glaucoma. Our patient underwent a large sclerokeratoplasty; however, because of the loss to follow-up, we do not know the possible complications he could postoperatively develop.

There are many possible mechanisms by which corneal complications resulting from crack cocaine may develop ${ }^{(4-5)}$. Cocaine can exert a direct toxic effect on the cornea by damaging epithelial plasma membranes and microvilli, or the repeated exposure to cocaine may result in decreased corneal sensation and poor blink reflex; moreover, the alkaline nature of crack cocaine could cause low-grade chemical burns to the cornea. Irritation caused by caustic fumes promotes mechanical trauma from vigorous eye rubbing on the face of an already altered epithelial framework and hypoesthetic state. Combined, all these potential factors create a favorable environment for infections. Our patient admitted to smoking crack cocaine for 4 months and also on the day of admission.

In conclusion, drug abuse remains a common problem nowadays. Ophthalmologists should be aware of the potential corneal complications related to drug abuse. Anterior staphylomas can result from untreated crack-cocaine-associated corneal ulcers, and managing these cases can be very difficult because of the high risk of non-compliance.

\section{REFERENCES}

1. Grieser EJ, Tuli SS, Chabi A, Schultz S, Downer D. Blueberry eye: acquired total anterior staphyloma after a fungal corneal ulcer. Cornea. 2009;28(2):231-2.

2. Matsubaraa A, Ozekia A, Matsunagaa N, Nozaki M, Ashikari M, Shirai S, Ogura Y. Histopathological examination of two cases of anterior staphyloma associated with Peters' anomaly and persistent hyperplastic primary vitreous. Br J Ophthalmol. 2001;85(12): 1421-5.

3. Ghosheh FR, Ehlers JP, Ayres BD, Hammersmith KM, Rapuano CJ, Cohen EJ. Corneal ulcers associated with aerosolized crack cocaine use. Cornea. 2007;26(8):966-9.

4. Sachs R, Zagelbaum BM, Hersh PS. Corneal complications associated with the use of crack cocaine. Ophthalmology. 1993;100(2):187-91.

5. Pilon AF, Scheiffle J. Ulcerative keratitis associated with crack-cocaine abuse. Cont Lens Anterior Eye. 2006;29(5):263-7.

6. Stocker FW. A new technique for corneal mushroom grafts and its indication. Am J Ophthalmol. 1959;48(1):27-30.

7. Panda A, Sharma N, Angra SK, Singh R. Sclerokeratoplasty versus penetrating keratoplasty in anterior staphyloma. Ophthalmic Surg Lasers. 1999;30(1):31-6.

8. Yalxçindag FN, Celik S, Ozdemir O. Repair of anterior staphyloma with dehydrated dura mater patch graft. Ophthalmic Surg Lasers Imaging. 2008;39(4):346-7.

9. McHenry JG, Zeiter JH, Madion MP, Cowden JW. Corneal epithelial defects after smoking crack cocaine. Am J Ophthalmol. 1989;108(6):732. 